\title{
Spatial risk assessment on land subsidence in Beijing, China
}

\author{
$\underline{\text { L.Zhu }}^{\text {a }}$, Y. Chen ${ }^{b}$, H.L. Gong ${ }^{a}$, C. Liu ${ }^{a}$ and R. Wang ${ }^{c}$ \\ ${ }^{a}$ College of Resource Environment and Tourism, Capital Normal University, Beijing Key Laboratory of \\ Resource Environment and Geographic Information System, Beijing, China, ${ }^{b}$ CSIRO Land and Water, GPO \\ Box 1666, Canberra ACT 2601, Australia, Cooperative Research Centre for Irrigation Futures, Australia; \\ ${ }^{c}$ Beijing Institute of Hydrogeology and Engineering Geology, Beijing, China \\ E-mail: hi-zhulin@163.com
}

\begin{abstract}
Land subsidence is the lowering of land-surface elevation mainly due to human activities including groundwater withdrawal, oil or gas pumping. It is a critical threat to the sustainable development of urban constructions and social economy. Long-term and large-scale over-exploitation of groundwater, which supplies about two-thirds of the total regional water requirement, is a main cause for land subsidence in Beijing Municipality, China. It is essential to assess land subsidence risks for decision-makers to prevent the disaster. This study takes the up-middle part of alluvial-proluvial plain fan of the Chaobai River in Beijing as an example area, where Huairou Emergency Groundwater Resource Region is located. It evaluates the risk of land subsidence between 2006 and 2008 by adopting the analytical hierarchy process with sensitivity analysis (AHP-SA) method. Six criteria used for the evaluation are thicknesses of compressible sediment and the quaternary strata, changes in groundwater level of the unconfined and confined aquifer system, building density and recharge from precipitation infiltration. Criteria weights were determined on the basis of the interrelation coefficients between land subsidence and six factors. The highest weight was assigned to thickness of compressible sediment, followed by the thickness of quaternary strata and change in confined aquifer groundwater level. The weight of recharge from precipitation infiltration is the lowest. Distribution of land subsidence during the same period, which was derived by using Persistent Scatter Synthetic Aperture Radar Interferometry technique, was used to verify the accuracy of the risk assessment map.

The land subsidence risk map shows that the high risk region covers about $150 \mathrm{~km}^{2}$ and is mainly distributed in the southwest of the study area. Area of moderate risk accounts for nearly $1 / 3$ of the whole area which is in the middle-southern area. No-hazard zone is located in the northern area, which is the upper area of the alluvial-pluvial plain fan. The evaluation results are least sensitive to the recharge from precipitation infiltration. Risk map is more sensitive to the change of confined aquifer groundwater level in that when the weight changes for more than $\pm 2 \%$, an obvious shift between high and moderate subsidence risk regions occurs. The risk map is also sensitive to the thicknesses of the quaternary and compressible sediment. However, since these two factors cannot be controlled by human beings, it is necessary for decision-makers to pay more attention to limit the drawdown of groundwater level. The output of this study provides a better insight to land subsidence hazard management.
\end{abstract}

Keywords: $\quad$ land subsidence risk, Analytical Hierarchy Process (AHP), Sensitivity analysis, PS-InSAR 


\section{INTRODUCTION}

Land subsidence is the drop of land-surface elevation that takes place underground. It results in many problems, such as damages to under-ground pipelines, traffic lines and buildings, and causes environmentinduced geological disasters, such as ground fissure. Assessing land subsidence risk to mitigate any potential disasters is therefore necessary. Many studies have focused on measuring and monitoring technologies of ground displacements triggered by groundwater pumping or mine collapse, land subsidence modelling and land subsidence management. Several approaches can be adopted for subsidence risk assessment, including statistical models and expert system methods. These models include neuro-fuzzy inference system (ANFIS) (Park et al. 2012), artificial neural network (ANN) (Kim et al., 2009; Choi et al., 2010), weight of evidence (WOE) (Oh and Lee, 2010), multi-criteria decision model (Mancini et al., 2009), frequency ratio (FR) (Oh et al. 2011; Suh et al., 2013) and analytic hierarchy process (AHP) (Putra et al., 2011; Jiang et al., 2012; Huang et al., 2012). In particular, Oh and Lee (2010) employed various models, including FR, WOE, logistic regression (LR) and ANN models, to assess the danger of land subsidence. AHP coupled with a fuzzy combination operator was used to evaluate the subsidence hazard map (Hu et al., 2008; Choi et al., 2011). However, most of these models were adopted to study land subsidence resulted from coal mining. Few of them have sensitivity analysis associated with modelling results.

Beijing is a political and cultural center with an area of $6,390 \mathrm{~km}^{2}$. Groundwater supplies two-thirds of water resource in Beijing where over-drafting of aquifers is the major cause of subsidence. In 1999, area with accumulated land subsidence over $200 \mathrm{~mm}$ was found to be about $350 \mathrm{~km}^{2}$. Under the pressures of decreasing precipitation and increasing demand on water resource, five Emergency Groundwater Resource Regions (EGRR) have been built since 2001. As time goes on, land subsidence becomes more and more severe. The biggest accumulative ground subsidence reached 1,163 mm in 2009 (Yang et al., 2010). However, few studies are launched to investigate the risk of land subsidence due to the high-intensity and concentrative pattern of groundwater exploration in EGRR.

This study takes up-middle part of alluvial-pluvial plain fan of the Chaobai River in Beijing as a study area, where Huairou EGRR is located. The objective of is to explore land subsidence risks and the sensitivity of the impact factors on risk evaluation map by adopting a GIS-based multi-criteria tool named AHP-SA (Chen et al., 2010; Chen et al., 2013). The results will help improve the strategy of regional land subsidence and groundwater resource management to guarantee the safety of groundwater exploitation.

\section{THE STUDY AREA}

The study area is located in the up-middle part of alluvial-pluvial plain fan of the Chaobai River in Beijing, covering an area of $1,352 \mathrm{~km}^{2}$ (Figure 1). Precipitation is the main source of groundwater recharge and exploitation is the main way for groundwater discharge. The EGRR with an area of about $25 \mathrm{~km}^{2}$ was established in August 2003. It is situated in the region near Yanxi River and Huai River. There are 21 groups of groundwater-pumping wells originally planned for emergency. However, these groundwater pumping wells have been used for daily water supply instead of for emergency purpose to meet the large demand of water resources in Beijing. There are also some wells along the Chaobai River, which belongs to water-supplying factory.

\section{METHODS AND MATERIAL}

\subsection{GIS-based AHP-SA tool}

The analytical hierarchy process (AHP) coupled with sensitivity analysis (SA) was developed as an AHPSA tool by Chen et al. $(2009,2010)$ for multi-criteria decision-making in ArcGIS environment. The GISbased tool includes two procedures: AHP and SA. The AHP is to deal with the complex decision-

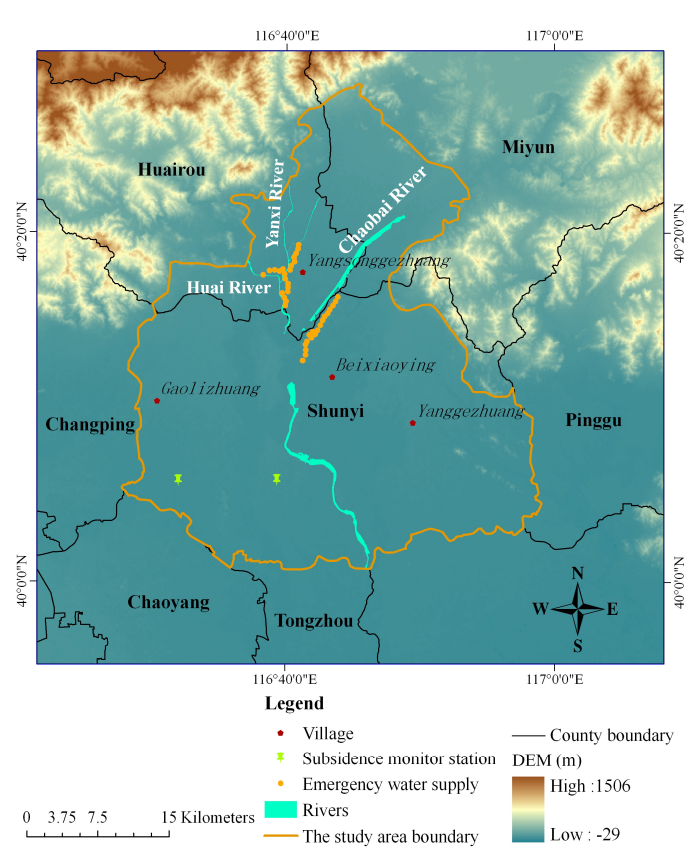

Figure 1. Location of the study area. 
making problem, which employs a pair wise comparison matrix to quantify weights for each criterion $\left(\omega_{i}\right)$ by taking the eigenvector corresponding to the largest eigenvalue of the matrix based on the expert system or measurement data. The calcuated equation is as followes:

$$
\begin{gathered}
\sum_{i=1}^{n} \omega_{i}=1 \\
\omega_{i}=\frac{\sum_{j=1}^{n} b_{i j}}{\sum_{i=1}^{n} \sum_{j=1}^{n} b_{i j}}
\end{gathered}
$$

where $b_{i j}$ is the normalized matrix of the pairwise comparison matrix.

MATLAB COM-Compliant component was used to implement AHP and to calculate criteria weights. The evaluation map can be determined from the sum of each criteria map layer times the calculated weight.

SA is a procedure to examine the impacts of changing criteria weights on the model outcomes in spatial dimension, and to identify criteria that are the most sensitive or stable to weight changes. The approach is changing one criteria weight at a time (OAT) with all other weights fixed. A specified range of weight deviations can be investigated through simulation runs. The results will then be compared against those derived based on the original criteria weights from the AHP process for sensitivity assessment.

The AHP-SA model is easier for non-experts to deal with multi-criteria decision-making problems and understand how changes in criteria weights affect evaluation outcomes spatially and quantitatively. This model has been successfully adopted for irrigated cropland suitability assessment in Australia (Chen et al., 2010; Chen and Paydar, 2012; Chen et al., 2013).

\subsection{Data set}

The overall goal of the study is to evaluate the risk of land subsidence. Six criteria were used for the assessment. They were presented as a series of spatial layers: thicknesses of compressible sediment and the quaternary strata, change in groundwater level of the unconfined and confined aquifer system, building density and recharge from precipitation infiltration. These spatial datasets were reclassified into four ranks. The ranking number from 1 to 4 represents low to high hazard risk. The threshold values for the rank of each criterion are given in Table 1.

Geological condition is the intrinsic factor for land subsidence. A total of 133 borehole datasets were collected to determine the thickness of compressible sediment and quaternary strata. Besides, excessive groundwater exploitation is another main reason for land subcidence. Therefore, groundwater level contours in June 2006 and June 2008 were used to delineate the changes of groundwater level changes. The ammount of recharge from precipitation affects groundwater levels, which in turn causes subsidence. The recharge was obtained by WetSpass model (Zhu et al., 2013), which is a distributed hydrological model based on water balance method. The input data of WetSpass model includes land use, soil texture, groundwater depth, digital elevation model, slope and meteorological data. And the output is groundwater recharge with a unit of milimeter. Increasing building area changed the total stress acting on the geological solid. Landsat TM (Thematic Mapper) images during the same period were collected to extract building area, which is used to reflect the static loading, using the maximum-likelihood supervised classification method. Persistent Scatter InSAR (Synthetic Aperture Radar Interferometry) technique was used to detect accumulative land deformation from the ENVISAT-ASAR images in order to verify the accuracy of final subsidence hazard evaluation map. A series of 24 ENVISAT-ASAR images with a resolution of $30 \mathrm{~m}$ were acquired from August 16, 2006 to December 3, 2008. Compared with the observed land subsidence from monitoring stations, the average accuracy of remotely sensed data is about $6 \mathrm{~mm}$. 
Table 1. Criteria and grade for risk assessment of land subsidence.

\begin{tabular}{|c|c|c|c|c|c|c|}
\hline \multicolumn{2}{|l|}{ Factors } & \multirow{2}{*}{$\begin{array}{l}\text { Code } \\
\text { name }\end{array}$} & \multicolumn{4}{|c|}{ Risk level and value } \\
\hline & & & $\begin{array}{l}\text { No } \\
(1)\end{array}$ & $\begin{array}{l}\text { Low } \\
(2)\end{array}$ & $\begin{array}{l}\text { Moderate } \\
\text { (3) }\end{array}$ & $\begin{array}{l}\text { High } \\
(4)\end{array}$ \\
\hline \multirow{2}{*}{$\begin{array}{l}\text { Geological } \\
\text { condition }\end{array}$} & Thickness of compressible sediment (m) & $\mathrm{C}$ & $<100$ & $100 \sim 200$ & $200 \sim 300$ & $>300$ \\
\hline & Thickness of quaternary strata (m) & Q & $<150$ & $150 \sim 250$ & $250 \sim 350$ & $>350$ \\
\hline \multirow[t]{2}{*}{$\begin{array}{l}\text { Hydrogeology } \\
\text { condition }\end{array}$} & $\begin{array}{l}\text { Change in groundwater level of unconfined } \\
\text { aquifer system }(\mathrm{m})\end{array}$ & $\mathrm{U}$ & $>0$ & $0 \sim-5$ & $-5 \sim-10$ & $<-10$ \\
\hline & $\begin{array}{l}\text { Change in groundwater level of second } \\
\text { confined aquifer system (m) }\end{array}$ & $\mathrm{Sc}$ & $>0$ & $0 \sim-5$ & $-5 \sim-10$ & $<-10$ \\
\hline \multicolumn{2}{|c|}{ Building density (\%) } & $\mathrm{Bd}$ & $<25$ & $25 \sim 50$ & $50 \sim 75$ & $>75$ \\
\hline \multicolumn{2}{|c|}{ Recharge from precipitation infiltration (mm) } & $\mathrm{R}$ & $>150$ & $100 \sim 150$ & $50 \sim 100$ & $0 \sim 50$ \\
\hline
\end{tabular}

\subsection{Determination of criterion weights}

Previous study showed that the correlation coefficients of the land subsidence and change of groundwater level, compressible sediments thickness and building areas from 1965 to 2005 are $0.46,0.64$ and 0.25 , respectively (Zhu et al., 2013). Combined with these coefficients and the best judgments from experts, the pairwise comparison in the AHP method were used to derive the weights of the six criteria, which employs the semantic scale with values from 1 to 9 (Saaty and Vargas, 1991) to rate the relative preference between two elements in the comparison matrix (Table 2). Determination of consistency ratio (CR) value is critical. Generally, commonly used threshold value is 0.10 (Saaty, 1997). CR in this study is 0.02 which means the derived weights are acceptable.

\section{RESULTS AND DISCUSSION}

\subsection{Land subsidence risk distribution}

The resultant risk map of current land subsidence is presented in Figure 2a. Hazard risk of land subsidence is divided into four ratings, stated as: high risk, moderate risk, low risk and no risk. The areas of high risk, moderate risk, low risk and no risk regions account for $11 \%, 34 \%, 25 \%$ and $30 \%$ of the study area. The high risk region is located at the southwest area, where the geological condition is prone to land subsidence, and the thickness values of compressible sediment and quaternary strata are more than 300 $\mathrm{m}$ and $350 \mathrm{~m}$. In Beijing, serious land subsidence

Table 2. Pairwise matrix and criterion weights.

\begin{tabular}{|l|l|l|l|l|l|l|l|}
\hline & $\mathrm{R}$ & $\mathrm{B}$ & $\mathrm{Q}$ & $\mathrm{C}$ & $\mathrm{U}$ & $\mathrm{Sc}$ & Weight \\
\hline $\mathrm{R}$ & 1 & $1 / 2$ & $1 / 5$ & $1 / 5$ & $1 / 4$ & $1 / 4$ & 0.0445 \\
\hline $\mathrm{Bd}$ & 2 & 1 & $1 / 3$ & $1 / 4$ & $1 / 2$ & $1 / 3$ & 0.0738 \\
\hline $\mathrm{Q}$ & 5 & 3 & 1 & 1 & 3 & 2 & 0.2848 \\
\hline $\mathrm{C}$ & 5 & 4 & 1 & 1 & 3 & 2 & 0.2968 \\
\hline $\mathrm{U}$ & 4 & 2 & $1 / 3$ & $1 / 3$ & 1 & $1 / 2$ & 0.1190 \\
\hline $\mathrm{Sc}$ & 4 & 3 & $1 / 2$ & $1 / 2$ & 2 & 1 & 0.1811 \\
\hline
\end{tabular}
compressible sediment is more than $250 \mathrm{~m}$ (Jiang et al., 2012). In the high risk region the changes of confined aquifer groundwater level and unconfined aquifer are $-0.6 \mathrm{~m}$ and $-1.78 \mathrm{~m}$, which are less than the change of groundwater level around the EGRR. The moderate risk regions are mainly in the middle-south of the study area. No risk region is mainly located in the north, where is the top of alluvial-pluvial plain fan as well. 

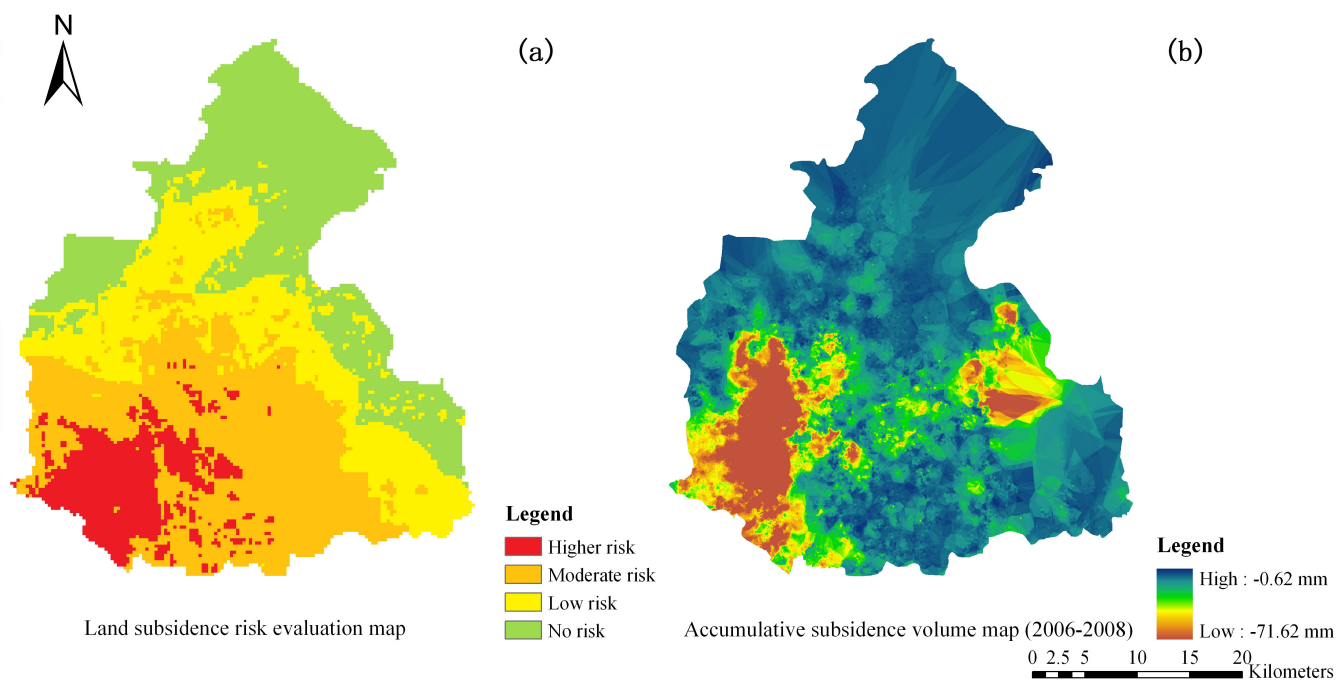

Figure 2. Land subsidence risk evaluation map (a) and accumulative subsidence volume map detected by PS-InSAR (b).

The map of accumulative land subsidence from 2006 to 2008, detected from PS-InSAR (Figure 2b), was used to verify the land subsidence risk map. In the high hazard region, the average accumulative subsidence value is about $20.23 \mathrm{~mm}$ and the maximum value is the $63.94 \mathrm{~mm}$. The average accumulative subsidence value is $7.05 \mathrm{~mm}$ in low risk region.

\subsection{Sensitivity of land subsidence risk to criterions}

The results of SA analysis are given in Figure 3. The percent change range of each criterion weight is from $20 \%$ to $20 \%$ on basis of the original weight. There are 41 runs for each criterion. Each run represents a weight change at $1 \%$ increment. It can be observed from Figure 3 that cell numbers of each risk rank do not change much while altering the weights of six criteria within defined range. The largest changing cells number is the 534 (the total cells number is 15014) when the weight of quaternary strata changes by $20 \%$. The evaluation results also shows similar change patterns when the weights of quaternary strata and the thickness of compressible sediment were altered. With the increasing weights of the two criteria, the areas of moderate risk region and low risk region decrease; however, the area of high risk region increases a lot. With the increasing weights of change of unconfined aquifer and confined aquifer, the area of moderate risk region shows obvious increasing trend and the area of high risk region decreases. These phenomena also reflect the integrated effect of geological effect, decreasing groundwater level and others inducing land subsidence.

The risk evaluation map is most sensitive to changes in confined aquifer groundwater level. When the weight of this criterion changes more than $\pm 2 \%$, the cell numbers change in all risk ranks. The obvious difference occurs between high and moderate subsidence risk regions. The risk map has the least sensitivity to recharge from the precipitation infiltration. Areas with the high risk rank are highly sensitive to the changes of confined aquifer groundwater table, quaternary strata, and the thickness of compressible sediment. Areas with the moderate risk rank are highly sensitive to the changes of confined aquifer groundwater table and quaternary strata. Low and no-hazard classes are low sensitive to the weight changes of the six evaluation criteria.

\section{CONCLUSIONS}

This study employs a GIS-based AHP-SA approach for evaluating land subsidence risks in the up-middle part of alluvial-pluvial plain fan of the Chaobai River in Beijing. The resultant risk map was verified by the accumulative land subsidence detected by PS-InSAR technique. The accumulative land subsidence in the high risk region generally is larger and is mainly distributed in the southwest of the study area. The land subsidence risk map is most sensitive to the weight of confined aquifer groundwater table and highly sensitive to the thicknesses of the quaternary and compressible sediment. These are two criteria that cannot be controlled by human beings. It is more practical to take control of the confined groundwater level drawdown to reduce the risk of land subsidence in the region. 

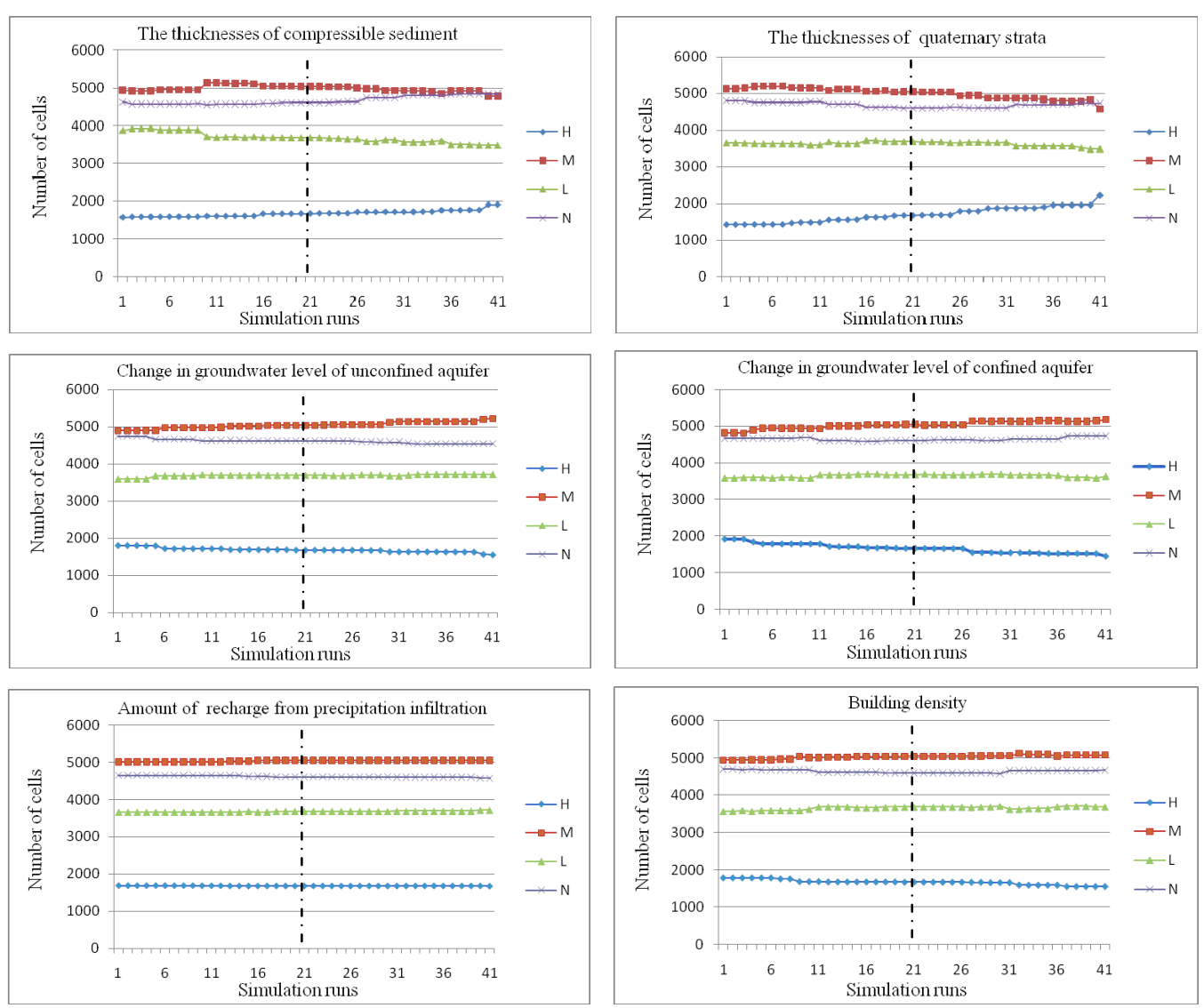

$$
\begin{aligned}
& \mathrm{H}=\text { High risk class } \\
& \mathrm{M}=\text { Moderate risk class } \\
& \mathrm{L}=\text { Low risk class } \\
& \mathrm{N}=\text { No risk class }
\end{aligned}
$$

Simulation $21=0 \%$ weight change (Base run) Simulation $1=-20 \%$ weight change Simulation $41=+20 \%$ weight change

Figure 3. Number cells of four risk ranks under different weights

\section{ACKNOWLEDGMENTS}

This work is founded by National Natural Science (No.41201420) and Beijing Nova Program (No.Z111106054511097).

\section{REFERENCES}

Chen, Y., Yu, J., Shahbaz, K., and Xevi, E. (2009). A GIS-Based Sensitivity Analysis of Multi-Criteria Weights. In Anderssen, R.S., R.D. Braddock and L.T.H. Newham (eds)18th World IMACS Congress and MODSIM09 International Congress on Modeling and Simulation, Modeling and Simulation Society of Australia and New Zealand and International Association for Mathematics and Computers in Simulation, July 2009, pp. 3137-3143. ISBN: 978-0-9758400-7-8.

Chen, Y., Yu, J., and Khan, S. (2010). Spatial sensitivity analysis of multi-criteria weights in GIS-based land suitability evaluation. Envriomental Modelling \& Software, 25:1582-1591.

Chen, Y., Yu, J., and Khan, S. (2013). The spatial framework for weight sensitivity analysis in AHP- based multi-critria decision making. Environmental Modeling \& Software. DOI: 10.1016/j.envsoft.2013.06.010.

Choi, J., Oh, H.J., Won, J.S., and Lee, S. (2010). Validation of an artificial neural network model for landslide susceptibility mapping. Environ Earth Sci, 60:473-483. DOI: 10.1007/s12665-009-0188-0

Choi, J.K., Won, J.S., and Lee, S. (2011). Integration of a subsidence model and SAR interferometry for a coal mine subsidence hazard map in Taebaek, Korea. International Journal of Remote Sensing, 32(23): 8161-8181. 
Huang. B.J. Shu. L.C., and Yang, Y. S. (2012). Groundwater Overexploitation Causing Land Subsidence:Hazard Risk Assessment Using Field Observation and Spatial Modelling. Water Resour Manage, 26:4225-4239.DOI 10.1007/s11269-012-0141-y

Hu, B.B., Jiang, Y.X., Zhou, J., Chen, Z.L., Wang D.Q., and Xu, S.Y. (2008). Assessment and Zonation ofLand Subsidence Disaster Risk of Tianjin Binhai Area. SCIENTIA GEOGRAPHICA SINIC, 5:693697.(in Chinese)

Jiang, Y., Jia, S.M., and Wang, H.G. (2012). Risk assessment and management of land subsidence in Beijing Plain. ZHONGGUO DIZHIZAIHAI YU FANGZHI XUEBAO, 1:55-60. (In Chinese)

Kim, K.D., Lee, S., and Oh, H.J. (2009). Prediction of ground subsidence in Samcheok City, Korea using artificial neural networks and GIS. Environ Geol, 58:61-70. DOI:10.1007/s00254-008-1492-9

Mancini, F., Stecchi, F., and Gabbianelli, G. (2009). GIS-based assessment of risk due to salt mining activities at Tuzla (Bosnia and Herzegovina).Engineering Geology, 109:170-182.

Oh, H.J., and Lee, S. (2010). Assessment of ground subsidence using GIS and the weights-of-evidence model. Engineering Geology, 115: 36-48.

Oh, H.J., and Lee, S. (2011). Integration of ground subsidence hazard maps of abandoned coal mines in Samcheok, Korea. International Journal of Coal Geology, 86:58-72.

Oh, H.J., Ahn, S.C., Choi, J.K., and Lee, S. (2011). Sensitivity analysis for the GIS-based mapping of the ground subsidence hazard near abandoned underground coal mines. Environ Earth Sci, 64:347-358, DOI: $10.1007 / \mathrm{s} 12665-010-0855-1$

Park, I., Choi J., Lee, M.J.,and Lee, S. (2012). Application of an adaptive neuro-fuzzy inference system to ground subsidence hazard mapping. Computers \& Geosciences, 48: 228-238.

Putra D.P.E, Setianto1 A., Keokhampuil K., and Fukuoka, H. (2011). Land Subsidence Risk Assessment Case Study: Rongkop, Gunung Kidul, Yogyakarta-Indonesia. The 4th AUN/SEED - Net Regional Conference on Geo - Disaster Mitigation in ASEA, 25 - 26, October, 2011, Conference.

Saaty, T.L. (1997). A scaling method for priorities in hierarchical structures. Journal of Mathematical Psychology, 15:231-281.

Saaty, T.L. and Vargas, L.G. (1991). Prediction, Projection and Forcasting. Kluwer Academic Pbulisher,251 pp., Dordrecht.

Suh, J., Choi, Y., Parkh, D., Yoon, S.H., and Go, W.R. (2013).Subsidence Hazard Assessment at the Samcheok Coalfield, South Korea: A Case Study Using GIS. Environmental \& Engineering Geoscience, XIX(1): 69-83.

Yang, Y., Jia, S.M., and Wang, H.G. (2010). The status and development of land subsidence in Beijing Plain. SHANGHAI GEOLOGY. 24(6):956-964. (In Chinese)

Zhu, L., Gong, H.L., Li, X.J., Li, Y.Y., Su, X.S., and Guo, G.X. (2013). Comprehensive analysis and artificial intelligent simulation of land subsidence of Beijing, China. Chinese Geographical Science, 23(2): $237-248$

Zhu, L., Liu, C., Li, X.J., Guo, G.X., and Pan, Y. (2013). A Study on precipitation infiltration change in Beijing Plain in the context of urbanization. Earth Science-Journal of China University of Geosciences, 38(5):1065-1072 (In Chinese) 